\title{
PENGARUH TEMPERATUR KALSINASI TERHADAP SIFAT MEKANIK MATERIAL SCAFFOLD HIDROKSIAPATIT DARI TULANG KAMBING
}

\author{
Setiawan Eka Prawira ${ }^{1}$, Joko Triyono ${ }^{1}$, Teguh Triyono ${ }^{1}$ \\ ${ }^{1}$ Teknik Mesin - Universitas Sebelas Maret \\ e-mail addres : prawira_eka@yahoo.co.id
}

\begin{tabular}{|c|c|}
\hline Keywords: & Abstract : \\
\hline $\begin{array}{l}\text { Sheep hydroxyapatite, SHA, } \\
\text { Biomaterial, Calcination, SEM, } \\
\text { Bone Graft }\end{array}$ & 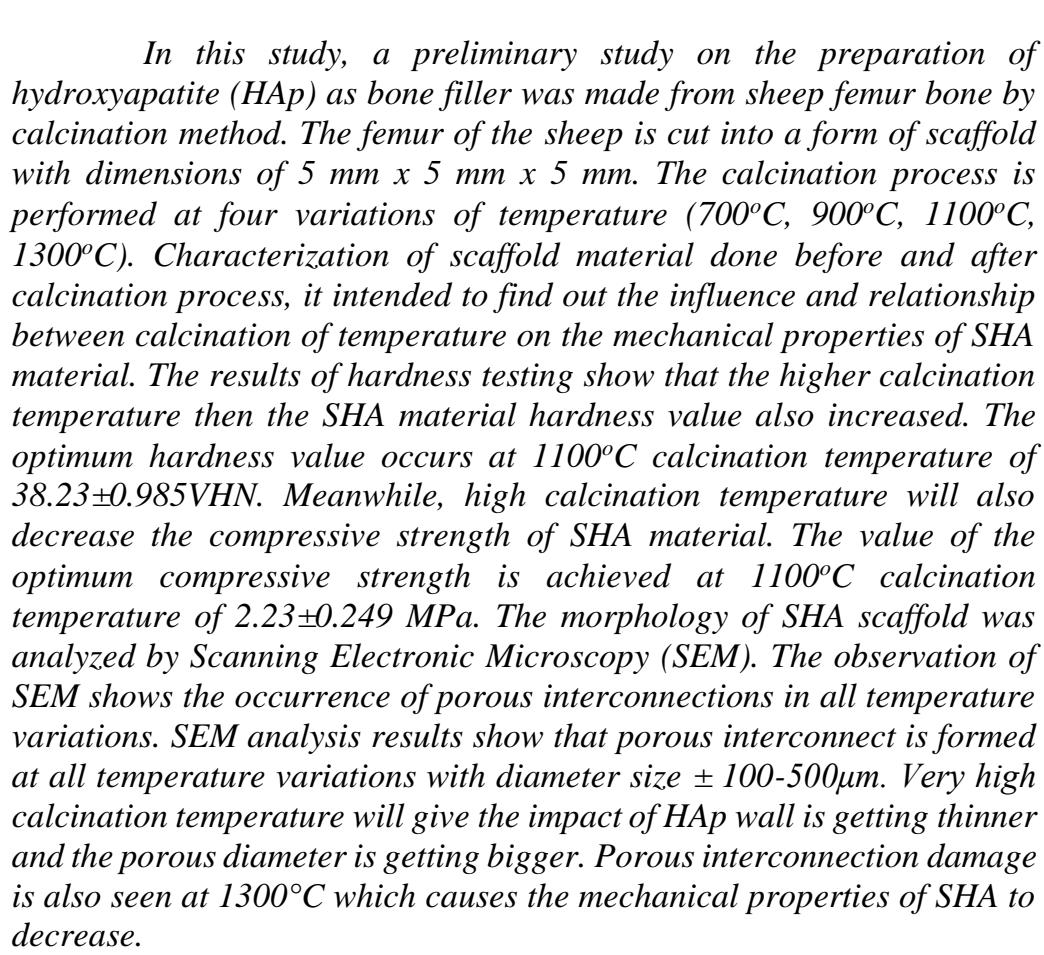 \\
\hline
\end{tabular}

\section{PENDAHULUAN}

Penggunaan bone graft atau bone filler sebagai bahan pengisi tulang di Indonesia terus meningkat dari tahun ke tahun seiring bertambahnya kasus fraktur yang sebagian besar disebabkan oleh tingginya angka kecelakaan. Dengan adanya graft tulang maka tulang yang rusak dapat dilakukan rekonstruksi sebagai solusi dari berbagai kasus fraktur yang terjadi di Indonesia. Metode rekonstruksi tulang yang umum dipakai saat ini adalah dengan cara implan atau cangkok tulang (bone grafting). Metode cangkok tulang berdasarkan klasifikasi asal material bone graft dari donornya mencakup metode allograft yakni pengganti tulang dari manusia lainnya, autograft yakni pengganti tulang dari bagian lain di tubuh pasien, dan xenograft yakni pengganti tulang dari hewan [1].

Material bone graft tipe allograft dan xenograft memiliki kelemahan yaitu kecenderungan adanya reaksi imun, penolakan oleh jaringan tubuh, serta kemungkinan penularan penyakit [2]. Teknik autograft dan allograft memerlukan tindakan bedah tambahan yang dapat menyebabkan trauma. Selain itu teknik ini juga dapat memperpanjang waktu bedah dan biaya perawatan [3].

Solusi untuk mengatasi resiko yang ditimbulkan dari beberapa metode rekonstruksi tulang tersebut maka diciptakanlah Hidroksiapatit (HAp). Hidroksiapatit merupakan mineral alami dari senyawa apatit kalsium fosfat yang berupa garam kristal dengan rumus $\mathrm{Ca}_{10}\left(\mathrm{PO}_{4}\right)_{6}(\mathrm{OH})_{2}$. HAp merupakan senyawa kalsium apatit yang paling stabil dibandingkan dengan kalsium fosfat lainnya, yaitu oktakalsium fosfat (OKF), dikalsium fosfat dihidrat (DKFD), dan trikalsium fosfat (TKF) [4].

Pengaruh temperatur kalsinasi terhadap sifat mekanik dari scaffold HAp diharapkan dapat diketahui dalam penelitian ini. Selain itu, hasil penelitian ini juga dapat dijadikan rujukan referensi untuk pengembangan penelitian berikutnya tentang 
pembuatan hidroksiapatit berbahan dasar limbah tulang kambing.

\section{METODOLOGI PENELITIAN}

Pembuatan Spesimen Scaffold SHA

Langkah awal yang dilakukan dalam penelitian yaitu menyiapkan tulang kambing bagian pangkal paha (femur). Tulang kambing diperoleh dari tempat pemotongan ternak kambing di Jalan Tahu, Kelurahan Gelung, Kecamatan Paron, Kabupaten Ngawi, Provinsi Jawa Timur. Tulang tersebut kemudian dibersihkan dari daging dan lemak yang masih tersisa dan menempel akibat bekas pemotongan. Setelah pembersihan, tulang kemudian direbus selama 2 jam sebanyak 3-5 kali untuk menghilangkan minyak dan bau amis. Tahap selanjutnya yaitu pengeringan tulang dengan cara dijemur di bawah terik matahari. Proses pengeringan ini dilakukan kurang lebih selama 1-3 hari. Setelah tulang benar-benar kering kemudian tulang dipotong dengan mesin gergaji tulang (bone saw) dan selanjutnya dilakukan finishing dengan cutter agar didapatkan bentuk/potongan spesimen berdimensi $5 \mathrm{~mm} \times 5 \mathrm{~mm} \times 5 \mathrm{~mm}$.

\section{Proses Kalsinasi}

Pada proses kalsinasi scaffold tulang kambing telah ditentukan melalui empat variasi suhu, yaitu $700^{\circ} \mathrm{C}, 900^{\circ} \mathrm{C}, 1100^{\circ} \mathrm{C}$ dan $1300^{\circ} \mathrm{C}$. Furnace yang digunakan untuk proses kalsinasi spesimen scaffold SHA yaitu Kejia Furnace KJ-1700X. Proses kalsinasi scaffold tulang kambing pada tiap-tiap variasi dimulai dari suhu ruangan $27^{\circ} \mathrm{C}$, dengan kenaikan temperatur $10^{\circ} \mathrm{C}$ per menit, waktu penahanan (holding time) selama 2 jam, kemudian yang terakhir yaitu proses pendinginan hingga mencapai suhu ruangan $27^{\circ} \mathrm{C}$.

\section{HASIL DAN PEMBAHASAN}

Analisa Pengaruh Temperatur Kalsinasi Terhadap Perubahan Warna Scaffold SHA

Perubahan warna sampel scaffold SHA untuk masing-masing variasi temperatur kalsinasi ditunjukkan pada Tabel 1.

Tabel 1. Perubahan warna scaffold SHA sebelum dan sesudah kalsinasi

\begin{tabular}{|c|c|c|}
\hline Temperatur & Scaffold SHA & Warna \\
\hline Sebelum & & \\
kalsinasi & sebelum Kalsinasi & Recoklatan \\
& & \\
\hline
\end{tabular}

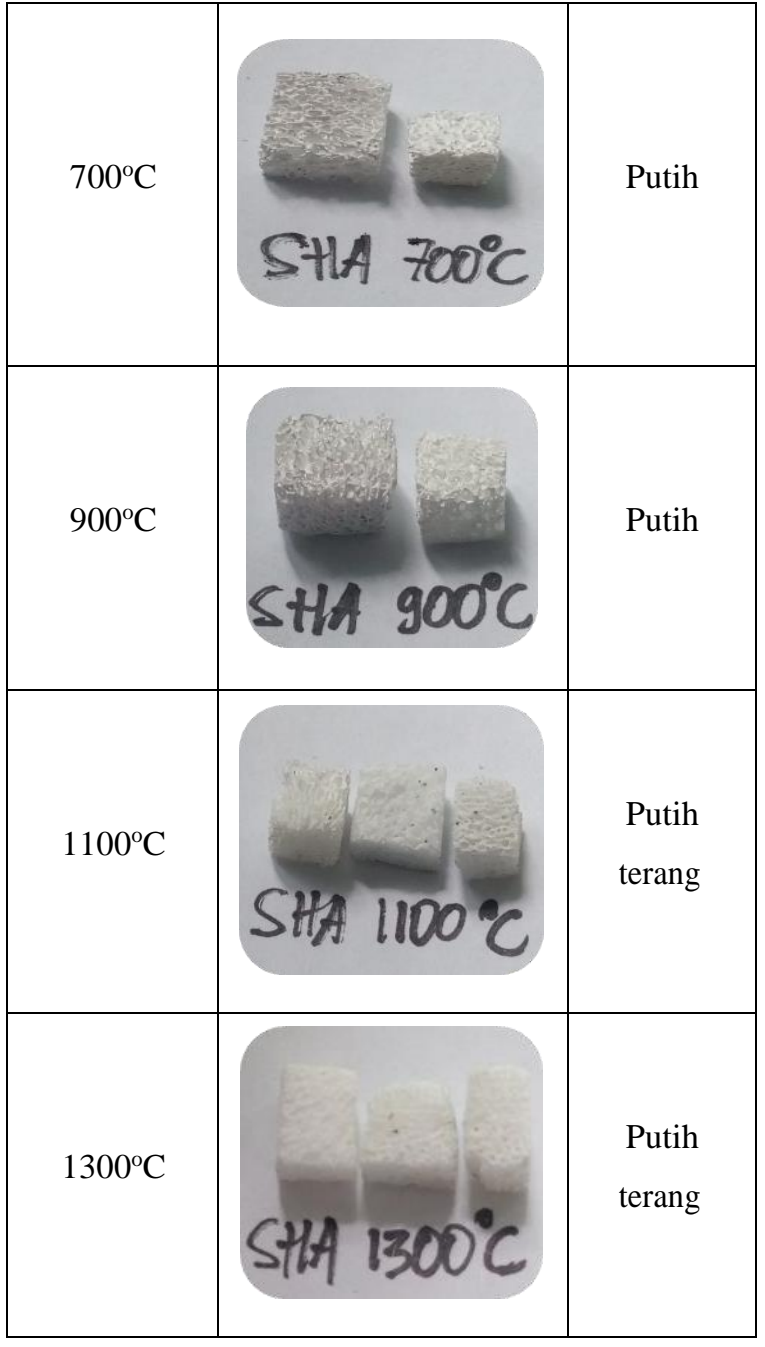

Dari Tabel 1, terlihat jelas bahwa sampel scaffold SHA sebelum dikalsinasi masih berwarna putih kecokelatan. Hal itu menandakan bahwa di dalam tulang tersebut masih terkandung material organik. Setelah dikalsinasi mencapai temperatur variasi $700^{\circ} \mathrm{C}$, terjadi perubahan warna yang cukup signifikan. Warna sampel tulang kambing pada variasi temperatur $700^{\circ} \mathrm{C}$ berubah menjadi putih. Sementara itu, pada temperatur $900^{\circ} \mathrm{C}$ warna tulang kambing yang dihasilkan tidak jauh berbeda dengan proses kalsinasi tulang kambing pada temperatur $700^{\circ} \mathrm{C}$. Proses kalsinasi sampel scaffold tulang kambing pada variasi temperatur $900^{\circ} \mathrm{C}$ juga dihasilkan warna putih. Hal ini terjadi karena selama proses kalsinasi pada variasi temperatur $700^{\circ} \mathrm{C}$ dan $900^{\circ} \mathrm{C}$ terjadi penguraian material organik. Itu artinya zat-zat organik yang terkandung di dalam tulang kambing telah hilang ketika temperatur kalsinasi mencapi temperatur $700^{\circ} \mathrm{C}$ dan $900^{\circ} \mathrm{C}$. Analisa ini diperkuat dengan penelitian yang pernah dilakukan Ooi, dkk (2006) [5] yang melaporkan bahwa tulang yang dikalsinasi pada suhu 
$\geq 700^{\circ} \mathrm{C}$, warna sampel menjadi putih, menunjukkan hilangnya zat organik pada tulang. Perubahan warna tulang ini diyakini terkait dengan proses terbakarnya dari matriks organik (protein dan kolagen).

Sementara itu warna sampel SHA tulang kambing yang dihasilkan pada kalsinasi variasi temperatur $1100^{\circ} \mathrm{C}$ adalah putih terang. Hal serupa juga terjadi pada kalsinasi SHA pada $1300^{\circ} \mathrm{C}$. Warna sampel scaffold tulang kambing yang dihasilkan pada kalsinasi variasi suhu $1300^{\circ} \mathrm{C}$ juga terlihat putih terang. Warna putih terang ini terjadi karena pada kalsinasi temperatur $1100^{\circ} \mathrm{C}$ dan $1300^{\circ} \mathrm{C}$, sampel SHA mulai terdekomposisi dan mulai berubah ke fase lain. Analisa ini diperkuat dengan penelitian yang pernah dilakukan oleh Niakan, dkk (2015) [6] yang melaporkan bahwa HAp terdekomposisikan ke fase lain dari kalsium fosfat seperti tri-kalsium fosfat (TCP) bila dikalsinasi pada suhu lebih dari $1000^{\circ} \mathrm{C}$, sehingga suhu kalsinasi memainkan peran penting dalam mengendalikan stabilitas fase HAp dan sifat mekanik. Ooi, dkk (2006) [5] dalam penelitiannya juga menambahkan bahwa hasil yang diperoleh dari analisis FTIR menunjukkan bahwa tulang secara bertahap melepaskan ion $\mathrm{OH}-$ pada suhu kalsinasi diatas $1100^{\circ} \mathrm{C}$.

Dari analisa hasil kalsinasi sampel SHA dan penjelasan Ooi, dkk (2006) [5], Niakan (2015) [6] di atas dapat disimpulkan bahwa suhu kalsinasi memainkan peran penting dalam mengendalikan stabilitas fase HA. Perubahan warna yang terjadi pada sampel SHA variasi $700^{\circ} \mathrm{C}$ dan $900^{\circ} \mathrm{C}$ dari kuning kecokelatan menjadi putih setelah proses kalsinasi disebabkan oleh adanya penguraian zat organik (protein dan kolagen), sedangkan perubahan warna yang terjadi pada sampel SHA variasi $1100^{\circ} \mathrm{C}$ dan $1300^{\circ} \mathrm{C}$ setelah proses kalsinasi menjadi putih agak terang dikarenakan SHA terdekomposisi ke fase trikalsium fosfat (TCP).

\section{Analisa Uji Kekerasan (Vickers Hardness Tester)}

Dari pengujian yang telah dilakukan dapat diketahui bahwa temperatur kalsinasi memiliki pengaruh terhadap sifat mekanik material scaffold SHA. Pengujiannya digunakan alat uji Vickers Microhardness berdasarkan ASTM E384-11e1 dengan metode pembebanan 25 gf dan waktu penekanan indentor selama 10 detik. Data yang telah diperoleh selanjutnya disajikan dalam bentuk grafik yang dapat dilihat pada Gambar 1.

Dari grafik pada Gambar 1, secara umum terlihat bahwa nilai kekerasan scaffold SHA mengalami peningkatan, mulai dari variasi temperatur kalsinasi $700^{\circ} \mathrm{C}$ hingga $1300^{\circ} \mathrm{C}$. Hasil pengujian sampel scaffold SHA pada $700^{\circ} \mathrm{C}$ memeliki nilai kekerasan terendah yakni $16,73 \pm 0,612 \mathrm{VHN}$, sedangkan pada variasi temperatur kalsinasi $900^{\circ} \mathrm{C}$, nilai kekerasan sampel scaffold SHA mengalami kenaikan menjadi $18,98 \pm 0,172$ VHN. Nilai kekerasan sampel SHA terus mengalami kenaikan hingga mencapi angka kekerasan optimum yaitu sebesar $38,23 \pm 0,985 \mathrm{VHN}$ pada temperatur kalsinasi $1100^{\circ} \mathrm{C}$. Fenomena naiknya nilai kekerasan sampel scaffold SHA mulai dari variasi temperatur kalsinasi $700^{\circ} \mathrm{C}$ hingga $1100^{\circ} \mathrm{C}$ disebabkan oleh terjadinya proses dekarbonasi dan dehidroksilasi material SHA [7]. Hilangnya unsur organik dan berubahnya scaffold SHA tulang kambing menjadi fase kristal hidroksiapatit setelah proses kalsinasi inilah yang juga menjadi penyebab nilai kekerasan sampel kontrol lebih rendah dari scaffold SHA setelah dikalsinasi.

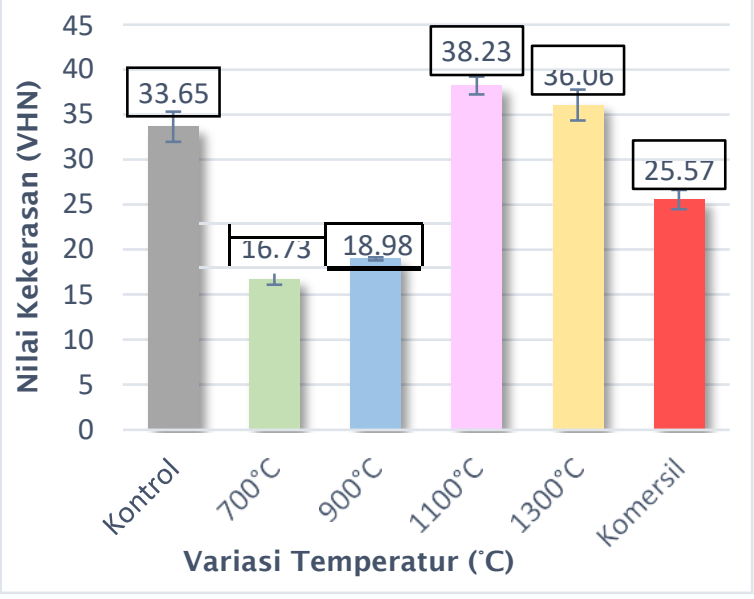

Gambar 1. Grafik hasil Uji Kekerasan SHA

Dari grafik pada Gambar 1 ditunjukkan bahwa nilai kekerasan sampel scaffold SHA kontrol hanya $33,65 \mathrm{VHN}$. Nilai tersebut lebih rendah dari nilai kekerasan sampel scaffold SHA setelah dikalsinasi pada variasi temperatur $1100^{\circ} \mathrm{C}$ yakni $38,23 \pm 0,985$ VHN, dengan selisih nilai kekerasannya sebesar 4,58VHN. Sementara itu, nilai kekerasan scaffold SHA pada variasi suhu kalsinasi $1100^{\circ} \mathrm{C}$ lebih tinggi dibandingkan nilai kekerasan HAp komersil. Hal itu karena HAp komersil dihasilkan dengan mengkalsinasi tulang sapi pada suhu $900^{\circ} \mathrm{C}$, sedangkan pada penelitian ini nilai kekerasan HAp tulang kambing pada suhu $900^{\circ} \mathrm{C}$ sebesar $18,98 \pm 0,172$ VHN. Selisihnya terpaut $6,59 \mathrm{VHN}$ lebih rendah dibanding nilai kekerasan HAp komersil, yakni

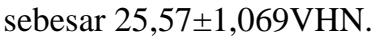

Berbeda pada variasi temperatur $1100^{\circ} \mathrm{C}$, pengujian kekerasan sampel scaffold SHA pada variasi temperatur $1300^{\circ} \mathrm{C}$, sampel scaffold SHA cenderung mengalami penurunan nilai kekerasan yakni $36,06 \pm 1,716$ VHN. Penurunan nilai kekerasan 
ini bisa terjadi karena temperatur $1300^{\circ} \mathrm{C}$ terlalu tinggi jika dipakai untuk proses kalsinasi scaffold HAp kambing yang bertujuan untuk menghasilkan HAp murni. Akibatnya, beberapa butir dari senyawa HAp menjadi rusak dan mulai membentuk fase lain yaitu tricalcium phosphate (TCP). Rusaknya kandungan HAp pada suhu kalsinasi di atas $1100^{\circ} \mathrm{C}$ juga pernah dilaporkan pada penelitian sebelumnya, yakni tentang sintesis HAp berbahan dasar tulang mandibula cumi sontong [8]. Dalam penelitian tersebut, scaffold HAp dibuat dalam bentuk serbuk dengan metode ball mill kemudian dikalsinasi pada variasi suhu $900^{\circ} \mathrm{C}$, $1000^{\circ} \mathrm{C}$, dan $1100^{\circ} \mathrm{C}$. Dari pengujian FTIR dan pengamatan SEM dijelaskan bahwa unsur $\mathrm{Ca}$ dan PO4-3 pada temperatur kalsinasi $1100^{\circ} \mathrm{C}$ berbentuk semi kristal atau amorphous berupa gumpalan atau agglomerate, sehingga temperatur $1100^{\circ} \mathrm{C}$ tidak cocok untuk kalsinasi yang bertujuan untuk menghasilkan HAp murni.

\section{Analisa Uji Kuat Tekan}

Temperatur kalsinasi memiliki pengaruh terhadap nilai kekuatan tekan material scaffold SHA. Hal itu dibuktikan dengan pengujian kuat tekan yang telah dilakukan menggunakan Universal Testing Machine (JTM Technology Machine, 0.5 T Capacity) berdasar pada ASTM F-451-95 dengan pembebanan load sebesar $100 \mathrm{~kg}$ dan dengan kecepatan penekanan $5 \mathrm{~mm} / \mathrm{menit}$. Data hasil pengujian kuat tekan beberapa sampel scaffold SHA dari beberapa variasi temperatur kalsinasi ditunjukkan pada Gambar 2 berikut.

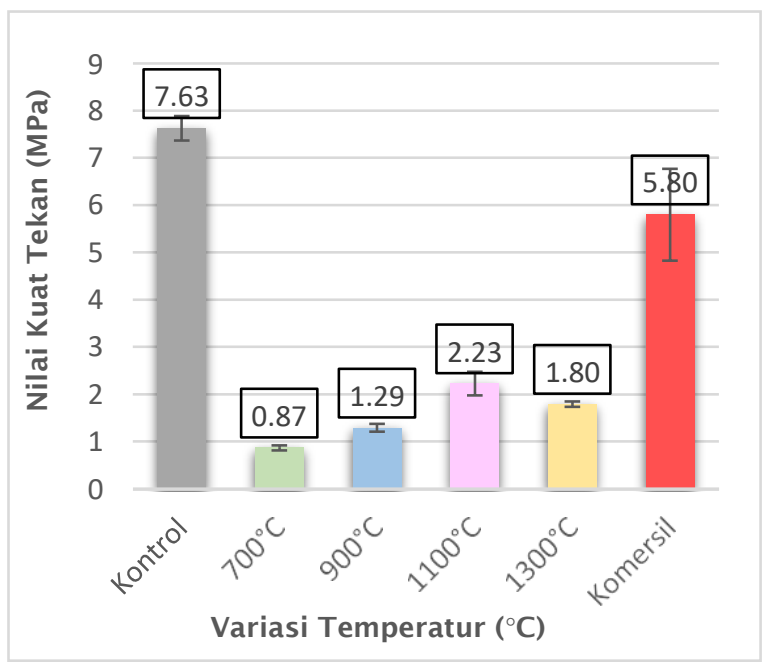

Gambar 2. Grafik hasil uji tekan scaffold SHA

Pada grafik ditunjukkan bahwa scaffold SHA tulang kambing untuk variasi temperatur $700^{\circ} \mathrm{C}$ memiliki nilai kuat tekan paling rendah yakni $0,87 \pm 0,053 \mathrm{MPa}$, pada temperatur kalsinasi $900^{\circ} \mathrm{C}$ nilai kekuatannya meningkat menjadi $1,29 \pm 0,081 \mathrm{MPa}$. Nilai kekuatan tekan yang optimum pada uji tekan sampel SHA ini diperoleh pada variasi

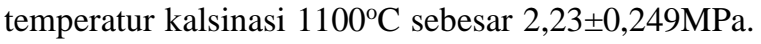
Peningkatan nilai kekuatan tekan SHA yang signifikan dari temperatur kalsinasi $700^{\circ} \mathrm{C}-1100^{\circ} \mathrm{C}$ ini terjadi karena scaffold SHA tulang kambing sudah mulai terbentuk HAp murni. Selain mulai terbentuknya hidroksiapatit murni, naiknya nilai kuat tekan tersebut juga dikarenakan adanya peningkatan kristalinitas ketika tulang kambing dikalsinasi pada temperatur $700^{\circ} \mathrm{C}$ hingga $1100^{\circ} \mathrm{C}$. Fenomena peningkatan kristalinitas HAp juga pernah dijumpai pada penelitian Ooi (2007) [5] yang melaporkan adanya peningkatan kristalinitas hidroksiapatit pada sampel BHA ketika temperatur kalsinasinya mencapai $600^{\circ} \mathrm{C}$ hingga $1000^{\circ} \mathrm{C}$

Pada Gambar 2 juga ditunjukkan bahwa nilai kekuatan tekan SHA tulang kambing mengalami penurunan setelah dikalsinasi di atas temperatur $1100^{\circ} \mathrm{C}$. Nilai kuat tekan SHA kambing pada temperatur $1300^{\circ} \mathrm{C}$ adalah $1,80 \pm 0,058 \mathrm{MPa}$. Selisih penurunan nilai kuat tekannya sebesar $0,43 \mathrm{MPa}$. Hal ini terjadi karena scaffold SHA semakin porous. Semakin tinggi temperatur yang digunakan untuk kalsinasi SHA maka porous interkoneksi yang terjadi pada sampel scaffold tulang kambing juga semakin besar. Besarnya porous inilah yang menyebabkan kekuatan tekan dari sampel scaffold tulang kambing menurun pada suhu temperatur $1300^{\circ} \mathrm{C}$. Menurut penelitian Solechan (2014) [8] temperatur kalsinasi yang tinggi mengakibatkan scaffold semakin rapuh dan porous, disamping itu kekuatan ikatan antar partikel semakin lemah. Lemahnya ikatan partikel mengakibatkan scaffold sangat getas, dan kekuatan tekan rendah.

Berdasarkan data hasil uji kuat tekan ini dapat disimpulkan bahwa secara garis besar, sifat kuattekan scaffold SHA berbahan dasar material tulang kambing sangat dipengaruhi oleh temperatur kalsinasi yang digunakan. Temperatur kalsinasi yang tinggi akan menurunkan sifat kuat tekan dari scaffold SHA tulang kambing. Hal tersebut dibuktikan dengan pengujian kuat tekan dan terlihat bahwa nilai kuat tekan scaffold SHA sebelum dikalsinasi (SHA kontrol) sebesar 7,63 $\pm 0,062 \mathrm{MPa}$ mengalami penurunan nilai kekuatan tekan setelah dikalsinasi pada beberapa variasi temperatur yang tinggi $\left(700^{\circ} \mathrm{C}, 900^{\circ} \mathrm{C}, 1100^{\circ} \mathrm{C}\right.$, $1300^{\circ} \mathrm{C}$ ). Turunnya nilai kuat tekan tersebut karena berkurangnya pengikat organik dan semakin porous (Tontowi dkk., 2012) [9]. Kesimpulan tersebut diperkuat juga oleh penelitian Solechan (2014)[8] yang menyatakan bahwa temperatur kalsinasi yang tinggi mengakibatkan scaffold semakin rapuh dan porous, disamping itu kekuatan ikatan antar partikel 
semakin lemah. Lemahnya ikatan partikel mengakibatkan scaffold sangat getas, dan kekuatan tekan rendah.

Pengamatan Scanning Electron Microscopy (SEM) Pada tabel 2 ditunjukkan gambar hasil SEM dari sampel scaffold SHA untuk variasi suhu kalsinasi $700^{\circ} \mathrm{C}, 900^{\circ} \mathrm{C}, 1100^{\circ} \mathrm{C}$ dan $1300^{\circ} \mathrm{C}$.

Tabel 2. Hasil foto SEM scaffold SHA

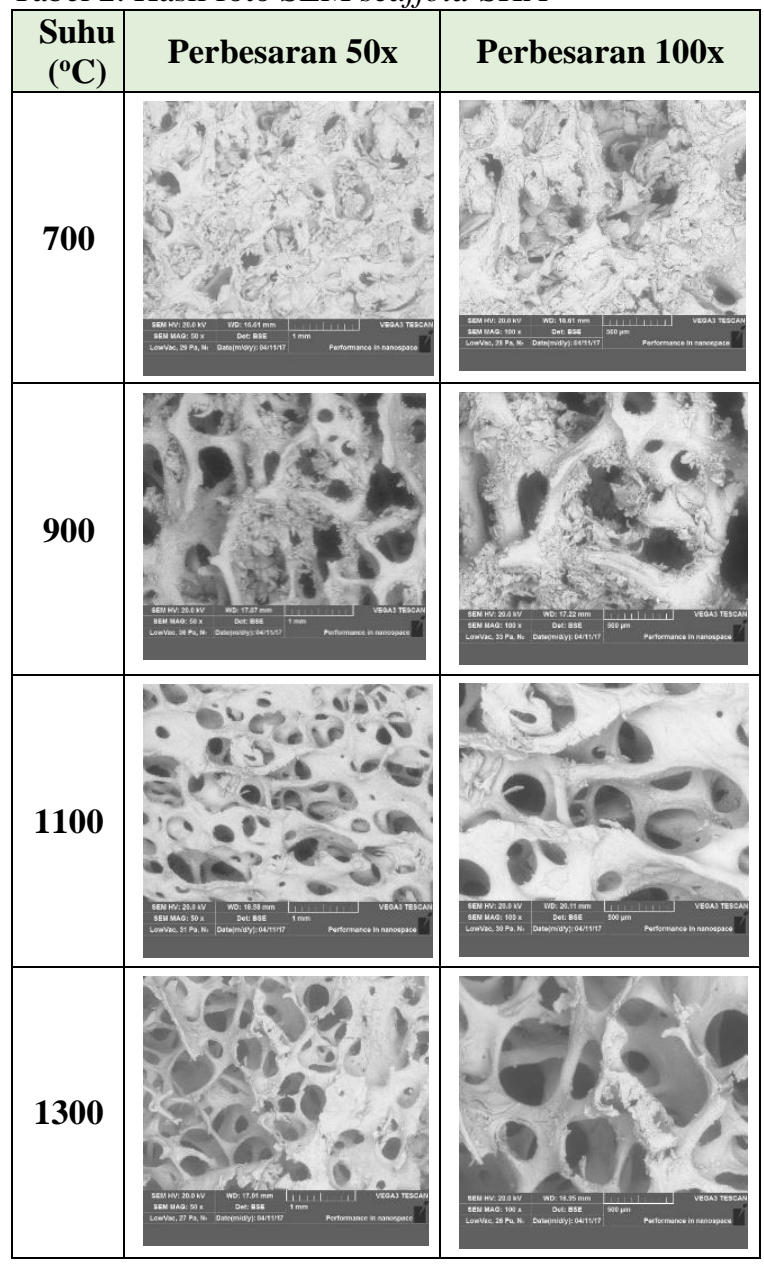

Dari Tabel 2, scaffold pada suhu kalsinasi $700^{\circ} \mathrm{C}$ terlihat adanya porous namun diameter interkoneksinya tidak begitu jelas sehingga pengamatan ukuran porous interkoneksi untuk sampel $700^{\circ} \mathrm{C}$ tidak dapat dilakukan di kedua perbesaran foto. Sementara itu dinding HAp pada scaffold SHA temperatur $700^{\circ} \mathrm{C}$ sudah mulai muncul dan dapat dilakukan pengamatan. Berbeda dengan suhu $700^{\circ} \mathrm{C}$, diameter porous interkoneksi pada variasi suhu $900^{\circ} \mathrm{C}$ mulai dapat teramati dengan jelas dengan ukuran diameter porousnya $\pm 100-200 \mu \mathrm{m}$ pada perbesaran 100x. Dinding HAp juga semakin terlihat jelas pada variasi temperatur $900^{\circ} \mathrm{C}$. Proses kalsinasi ini menghilangkan material organik dan menyisakan material anorganik yaitu hidroksiapatit. Pada temperatur $1100^{\circ} \mathrm{C}$, porous interkoneksinya sempurna dan teramati dengan jelas pada perbesaran 100x dengan ukuran diameter porous $\pm 100-400 \mu \mathrm{m}$. Sementara itu SHA pada variasi temperatur $1300^{\circ} \mathrm{C}$, porous interkoneksi cenderung membesar dan mulai mengalami kerusakan. Pada tabel 2 ditunjukkan adanya beberapa patahan porous interkoneksi yang menandakan bahwa kalsinasi pada temperatur $1300^{\circ} \mathrm{C}$ mengakibatkan kerusakan porous interkoneksi dari scaffold SHA kambing. Porous interkoneksi yang mengalami kerusakan tersebut berdiameter \pm 200 $500 \mu \mathrm{m}$. Sementara itu, dinding HAp pada variasi $1300^{\circ} \mathrm{C}$ juga nampak semakin tipis jika dibandingkan dengan dinding HAp pada variasi $1100^{\circ} \mathrm{C}$. Ukuran porous SHA yang semakin membesar dan dinding HAp yang semakin tipis inilah yang menyebabkan scaffold SHA menjadi lebih rapuh, sehingga menurunkan nilai kuat tekan scaffold SHA.

\section{KESIMPULAN}

Berdasarkan hasil pengujian dan pembahasan yang telah dilakukan, maka dapat ditarik kesimpulan sebagai berikut:

1. Temperatur kalsinasi semakin tinggi akan meningkatkan nilai kekerasan material scaffold SHA. Dari hasil uji Vickers Microhardness terhadap material scaffold SHA,nilai kekerasan tertinggi dicapai pada variasi temperatur $1100^{\circ} \mathrm{C}$ sebesar 38,23 $\pm 0,985 \mathrm{VHN}$.

2. Material scaffold SHA tulang kambing mengalami penurunan nilai kuat tekan setelah dikalsinasi pada temperatur $700^{\circ} \mathrm{C}, 900^{\circ} \mathrm{C}$, $1100^{\circ} \mathrm{C}$ dan $1300^{\circ} \mathrm{C}$. Dari ke empat variasi temperatur kalsinasi, nilai kuat tekan material SHA tertinggi dicapai pada temperatur kalsinasi $1100^{\circ} \mathrm{C}$ dengan nilai kuat tekan sebesar $2,23 \pm 0,249 \mathrm{MPa}$.

3. Pengamatan SEM material scaffold SHA pada temperatur kalsinasi $700^{\circ} \mathrm{C}, 900^{\circ} \mathrm{C}, 1100^{\circ} \mathrm{C}$ dan $1300^{\circ} \mathrm{C}$ menunjukkan adanya porous interkoneksi dengan ukuran diameter \pm 100 $500 \mu \mathrm{m}$. Temperatur kalsinasi yang tinggi mengakibatkan dinding hidroksiapatit (HAp) pada material scaffold SHA menjadi semakin tipis dan diameter porous interkoneksi menjadi semakin besar sehingga menurunkan sifat mekanik dari material scaffold SHA.

\section{DAFTAR PUSTAKA}

[1] K. Dahlan, S. U. Dewi, A. Nurlaila, and D. Soejoko, "Synthesis and Characterization of Calcium Phosphate/Chitosan Composites," vol. 
12, 2012.

[2] L. Bacáková and E. Filová, "Osteogenic Cells on Bio-Inspired Materials for Bone Tissue Engineering Osteogenic Cells on Bio-Inspired Materials for Bone Tissue Engineering," Physiol. Res., vol. 59, pp. 309-388, 2009.

[3] S. Jebahi and al. et, "Biologic Response to Carbonated Hydroxyapatite Associated with Orthopedic Device: Experimental Study in A Rabbit Model," Korean J. Pathol., vol. 46, no. 1, pp. 48-54, 2012.

[4] S. Gnanasundaram, S. Pal, C. Rose, and T. Sastry, "A Novel Bio-Inorganic Bone Implant Containing Deglued Bone, Chitosan and Gelatin," Bulletin of materials science vol. 24, pp. 415-420, 2001.

[5] C. Y. Ooi, M. Hamdi, and S. Ramesh, "Properties of Hydroxyapatite Produced by Annealing of Bovine Bone," Ceram. Int., vol. 33, pp. 1171-1177, 2007.

[6] A. Niakan, "Synthesis and Sintering of Hydroxyapatite Derived From Eggshells As A Calcium Precursor," Ceram. Int., no. February 2016, 2014.

[7] T. J. Levingstone, "Optimisation of Plasma Sprayed Hydroxyapatite Coatings Optimisation of Plasma Sprayed Hydroxyapatite Coatings," Dublin City University, Ireland, 2008.

[8] Solechan, "Pembuatan Material Sintesis Nano Hydroxyapatite Untuk Aplikasi Scaffolds Tulang Mandibula Dari Tulang Cumi Sontong Menggunakan Metode Kalsinasi,” vol. 5, no. 1, pp. 1-12, 2015.

[9] A. E. Tontowi, P. Dewo, E. T. Wahyuni, and J. Triyono, "Scaffold dari Bovine Hydroxyapatite dengan Polyvynialchohol Coating," Teknosains, vol. 1, no. 2, pp. 71-143, 2012. 